\title{
Construction Development and Its Impact on the Construction Enterprises Financial Results
}

\author{
OLHA PAVELKO ${ }^{1 *}$, INNA LAZARYSHYNA ${ }^{2}$, LIUDMYLA DUKHNOVSKA ${ }^{3}$, \\ SVITLANA SHAROVA ${ }^{4}$, TETIANA OLIINYK ${ }^{5}$, IRYNA DONENKO ${ }^{6}$ \\ ${ }^{1 *}$ Department of Accounting and Audit, NATIONAL UNIVERSITY OF WATER AND ENVIRONMENTAL \\ ENGINEERING, UKRAINE. E-mail: op.academ@gmail.com \\ ${ }^{2}$ Department of Statistics and Economic Analysis, NATIONAL UNIVERSITY OF LIFE AND ENVIRONMENTAL \\ SCIENCES OF UKRAINE, UKRAINE. \\ ${ }^{3}$ Department of Accounting and Auditing, NATIONAL UNIVERSITY OF FOOD TECHNOLOGIES, UKRAINE. \\ ${ }^{4}$ Department of Finance, Banking and Insurance, ZAPORIZHZHIA POLYTECHNIC NATIONAL UNIVERSITY, \\ UKRAINE. \\ ${ }^{5}$ Department of Finance, Banking and Insurance, ZAPORIZHZHIA POLYTECHNIC NATIONAL UNIVERSITY, \\ UKRAINE. \\ ${ }^{6}$ Department of Civil Engineering and Project Management, ZAPORIZHZHIA POLYTECHNIC NATIONAL \\ UNIVERSITY, UKRAINE.
}

\begin{abstract}
The article aims to monitor the construction development dynamics in Ukraine in recent years and substantiate its impact on the construction enterprises' financial results in general. The existing factors of development of construction in Ukraine are analyzed. The following groups: political, raw, industrial, environmental, consumer, infrastructure and investment, macroeconomic, financial, social, and innovative are identified. The influence of the factors mentioned above on the financial results of construction enterprises activity and the generating factors - income and expenses- is revealed. It was established that construction has become more active in recent years, with the highest residential and non-residential construction rates and the engineering structures construction in 2016, which were observed in Kyiv. Each year, the largest capital investments are characterized by engineering structures, in contrast to residential and non-residential buildings. The maximization of income and cost minimization make for improving the efficiency of the management of construction enterprises, which represents their ultimate goal. The conducted research gives reasons to state the significant role of the country macroeconomic environment in the construction enterprises functioning and the purport of their financial results. Construction development directions in the present conditions, the methodology, and construction enterprise accounting organization are covered.
\end{abstract}

Keywords: Construction, accounting, building enterprise, profit.

JEL Classification: D22; M40

Recibido: 11 de Marzo de 2021

Aceptado:21 de Marzo de 2021 


\section{Introduction.}

There is a significant increase in construction works carrying out by enterprises operating in the construction industry in the post-crisis period in Ukraine. This type of economic activity has a considerable impact on country development as a whole and the consequences of the subject's management of other types of economic activity. At the international level, the index "Jones Lang LaSalle Global Real Estate Transparency Index" (from now on referred to as "GRETI") is an indicative part of the real estate market assessment. In 2010, Ukraine ranked 47th in the overall rating (GRETI index - 3.14), in 2016 - 75th place (GRETI index - 3.66). According to the results of 2016, Ukraine has fallen to the real estate market with low transparency in the overall GRETI rating.

The net loss of construction companies in 2017 was eventually transformed into profit. The above confirms the increase of construction enterprises activity undoubtedly affected by the factors of macro- and microenvironment, which, as a rule, remain beyond the attention of scientists.

In construction, as in one of the priority economic activities, there is a significant recovery in the post-crisis period, as evidenced by the executed construction works volume growth and construction enterprises augmentation of the positive financial result value. Factors, investigated from a macroeconomic point of view, contributed significantly to the marked in-crease in this area [1]. Accordingly, attention should be paid to their impact on the construction companies' financial results, which are undoubtedly traced and characterized by peculiarities.

Construction development directions in the present conditions, the methodology and construction enterprises accounting organization are covered in scientific developments: $N$. Muzhevich [2], N. Verhoglyadova, M. Goncharenko, D. Levchinsky, O. Shcheglova [3], Tkachenko V., Kwilinski A., Klymchuk M., Tkachenko I. [4]. Miśkiewicz R. \& Wolniak, R. [5]; Zakharkin et al. [6] have analyzed practical solutions of Industry 4.0. Given the project's results, they concluded that implementing the new solution based on digitalization caused increased energy and material efficiency, often forced by external factors stemming from competitive markets' operation $[7,8]$. Technological changes also require the application of IT technologies and communication systems in managing production. Corresponding to the modern trends of global financial business and entrepreneurship, the methodology of organizational modelling is a multilevel corporate business model of an international bank with executive and functional (business, functions, structure), technological, process role, regulatory, service, quantitative subsystems $[9,10]$.

Shpak, N., Seliuchenko, N., Kharchuk, V., Kosar, N., Sroka, W. [11] have offered the framework for evaluating product competitiveness implemented for the construction industry. Prokopenko et al. [12] have specified conceptual framework for investment and innovation security, as well as the methodological approach to its assessment. Binda et al. [13], Yashin S. \& Korobova [14] have conducted an assessment of the investment attractiveness of industrial enterprises.

The state of development of this economic activity type demonstrates the macroeconomic situation in Ukraine as a whole. Without detracting the significant contribution of scientists in this field due to the construction companies accounting main theoretical and methodological principles, it is worth noting that insufficiently researched were the construction development dynamics in recent years and its impact on the business entities' financial results.

The research aims to monitor the construction development dynamics in Ukraine in recent years and substantiate its impact on the construction enterprises' financial results.

\section{Research Methodology.}

Starting from 2010, the State Statistics Committee of Ukraine (now the State Statistics Service of Ukraine) records capital investments accounting in residential, non-residential buildings and engineering structures. The volume dynamics of which for 2010-2018 are shown in Fig. 1.

According to Fig. 1, it can be stated that the most considerable capital investment amount is carried out annually to engineering structures (bearing and, in some cases, fencing structures 
intended for the production processes execution, temporary people stay and movement, vehicles, cargoes, the liquid, and gaseous products hauling, the equipment, materials, products, etc. allocation). The capital investment volumes increasing in non-residential buildings are observed during 2015-2018.

Fig. 1. Capital investments dynamics by assets types of during 2010-2018

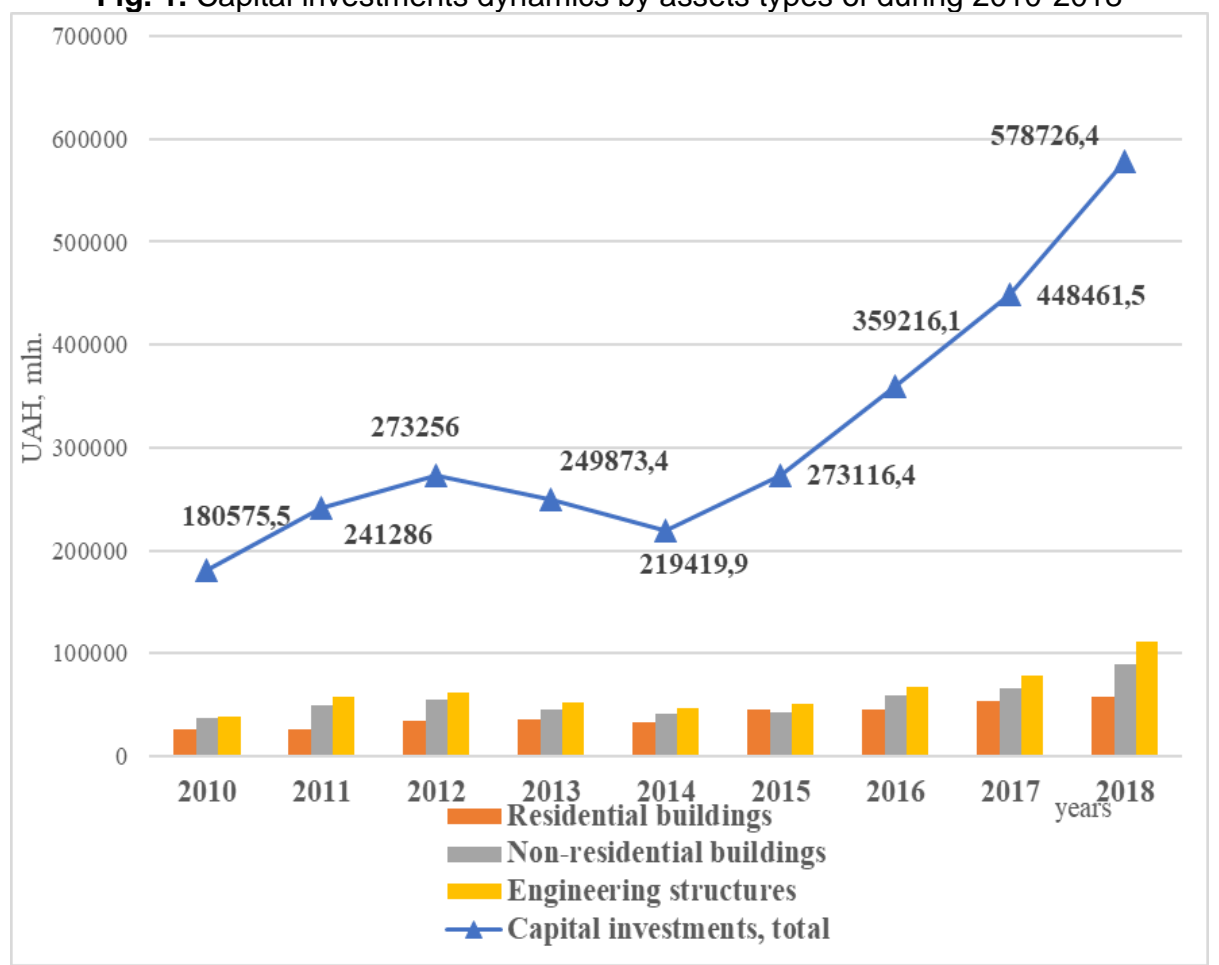

Source: formed by the authors according to the State Statistics Service of Ukraine (application dated December 12, 2019) [15].

Concerning housing construction in Ukraine as a whole, the highest indicators were in 2017-2018. In general, the domestic housing market formation is influenced by macroeconomic instability, information space opacity due to political instability, poor infrastructure development, real estate market participants' low professionalism, real estate market uneven segments development, inflation, etc. Residential housing acceptance by residential buildings type for the period 2010-2016 is shown in Table 1.

Table 1. Housing acceptance by residential buildings type (thousands of square meters)

\begin{tabular}{|c|c|c|c|c|}
\hline \multirow[b]{2}{*}{ Years } & \multirow[b]{2}{*}{ Total } & \multicolumn{3}{|c|}{ Including residential buildings } \\
\hline & & $\begin{array}{c}\text { single-family } \\
\text { houses }\end{array}$ & $\begin{array}{c}\text { with two or more } \\
\text { apartments }\end{array}$ & hostels \\
\hline 2010 & 8603.9 & 5713.0 & 2868.8 & 22.1 \\
\hline 2011 & 8685.3 & 4714.1 & 3938.0 & 33.2 \\
\hline 2012 & 9769.6 & 6465.1 & 3260.9 & 43.6 \\
\hline 2013 & 9949.4 & 5864.1 & 4023.7 & 61.6 \\
\hline 2014 & 9741.3 & 4553.4 & 5161.1 & 26.8 \\
\hline 2015 & 11044.4 & 5580.0 & 5435.2 & 29.2 \\
\hline 2016 & 9366.8 & 4089.2 & 5249.6 & 28.0 \\
\hline 2017 & 10206.0 & 4231.4 & 5934.9 & 39.7 \\
\hline 2018 & 8689.4 & 4247.7 & 4434.6 & 7.1 \\
\hline $\begin{array}{c}2018 \text { in \% to } \\
2010\end{array}$ & 101.0 & 74.4 & 154.58 & 32.1 \\
\hline
\end{tabular}


As we see from the data of Table 1, in 2015, the largest number of dwellings (11044.4 thousand square meters) was put into operation, where single-apartment residential buildings ( 5580 thousand sq. $\mathrm{m}$ ) prevailed. Still, the share of residential buildings with two or more apartments (with an area of 5435.2 thousand sq. $\mathrm{m}$ ) is also significant. Among the residential buildings total area put into operation, the vast majority is located in urban settlements.

The highest values of indicators are observed in 2015, both in terms of the built apartment number (120 thousand) and concerning acceptance into total area operation ( $259 \mathrm{~m} 2 \mathrm{per} 1000$ population). The unfinished construction can explain the indicators values reduction in 2016 because the object's construction, including residential, takes place over a long time. The executed construction works volume by construction product types in terms of Ukraine regions in 2019 can be traced according to Fig. 2.

Figure 2. Executed construction works volume by types of construction products by regions in 2019

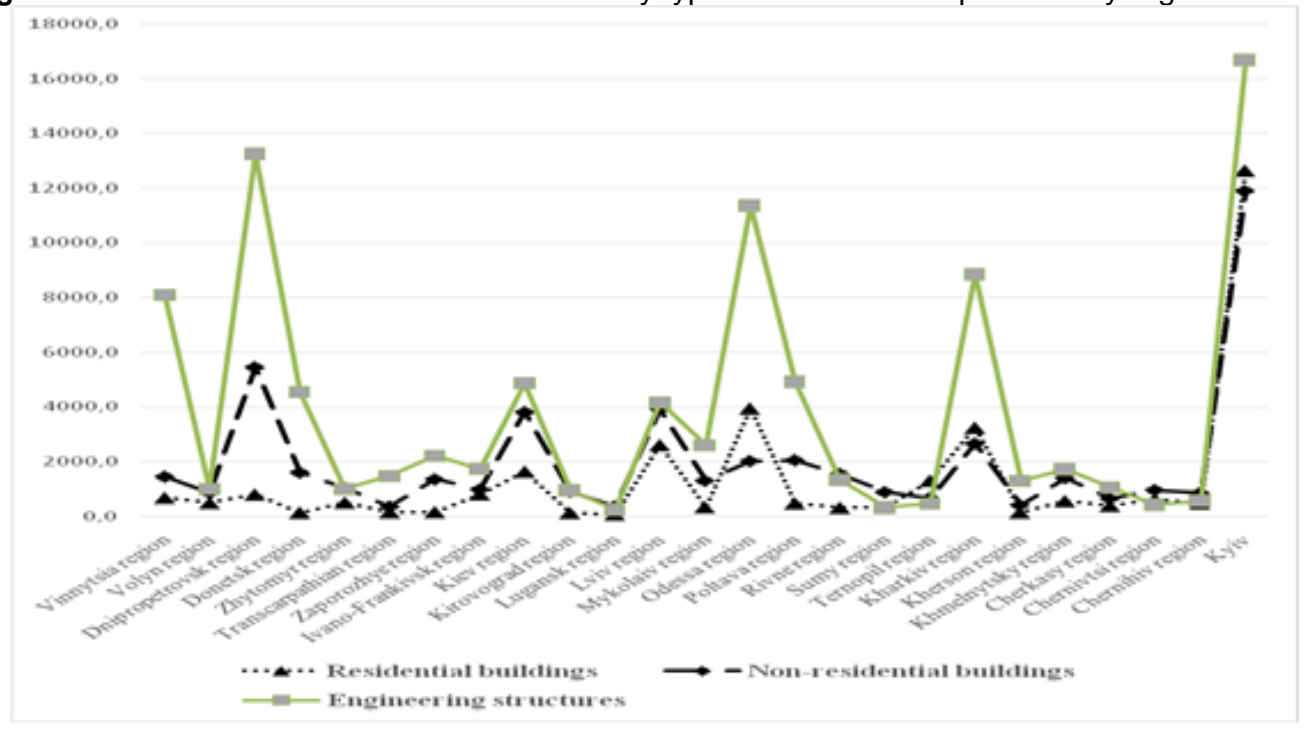

Source: formed by the authors according to the State Statistics Service of Ukraine (application dated January 12, 2020).

Thus, Kyiv's highest residential and non-residential construction indicators and the engineering structures construction in 2019 is observed. If we consider the construction executed works volume in general in the regions of Ukraine, then the largest share falls on engineering structures, and in 2019 their construction volume has increased significantly. The highest rates in 2019 are Kyiv and Kyiv region, Dnipro, Odesa, Poltava, Kharkiv, Khmelnytsky, and Vinnytsia regions. In these regions, the largest capital investments are made in residential, non-residential, and engineering facilities. Although a conclusion may review the main points of the paper, do not replicate the abstract as the conclusion. A conclusion might elaborate on the importance of the work or suggest applications and extensions.

In the capital investment structure by the financing sources, the largest share is occupied by own enterprises funds (70,8\% in 2018), households' expenditures on housing construction $(6,0 \%$ in 2018$)$, bank loans (7,7\% in 2018), and other loans (Fig. 3).

Consequently, it is at the enterprise's funds that most of the capital investments are made. The second-largest funding source in 2010-2013 was bank loans, starting in 2014, households' funds for housing construction, and can be explained by the rising interest rates on loans and legal entities lending complications. Instead, in other countries, mortgage lending contributed to economic growth, particularly in Germany (course Erhard), the United States (new Roosevelt rate). 
Figure 3. Capital investments structure by financing sources during 2010-2018

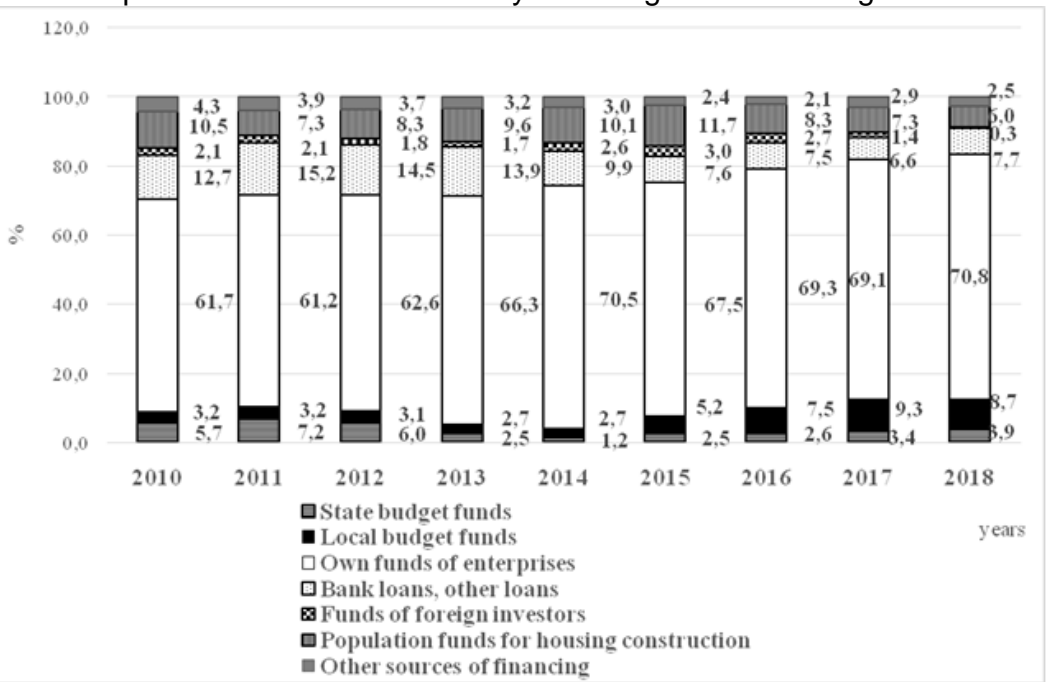

According to the State Statistics Service of Ukraine (application dated February 12, 2018), Source: Formed by the authors.

At the international level, the Jones Lang LaSalle Global Real Estate Transparency Index (GRETI) is an essential and indicative part of the real estate market assessment. GRETI is formed due to a unique survey of business leaders from Jones Lang LaSalle and LaSalle Investment Management, experts, and researchers (including accounting, finance, and legal experts) in all real estate markets. GRETI ranking leaders include the United States, United Kingdom, Australia, Canada, France, Finland, Sweden, Switzerland [16]. By the way, construction is one of the largest sectors of the UK economy. It contributes almost $£ 90$ billion to the UK economy (or 6.7\%) in value-added. It comprises over 280,000 businesses covering some 2.93 million jobs, equivalent to about $10 \%$ of total UK employment [17]. Developing countries are often characterized by low market transparency. Since 1999, Ukraine has been classified as opaque real estate markets since 2008 - markets with medium levels of transparency.

Thus, in 2010, our country took 47th place (GRETI index - 3.14), in 2016 - 75th place (GRETI index 3.66). According to the results of 2016, Ukraine gets into the real estate market with low transparency in the overall GRETI rating. However, it should be noted that the country has improved its posi-tion compared to the previous year due to the disclosure by some enterpris-es, their reports, and public sector publicity growth as ongoing reforms re-sult. The construction companies' results are shown in Fig. 4.

Figure 4. Net profit (loss) of enterprises engaged in construction in 2010-2018

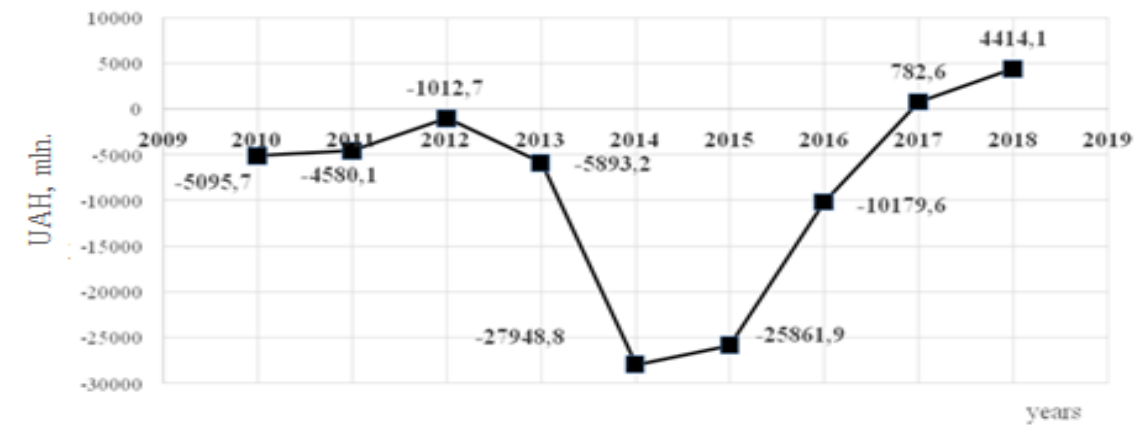

According to the State Statistics Service of Ukraine (application dated February 12, 2018), Source: Formed by the authors.

According to Fig. 4, the decrease in the construction enterprises' losses in 2010-2012, the financial result deterioration in 2013-2014, and improvements in 2017-2019 are observed. Their net profit (loss) formation and separate indicators dynamics are shown in the table. 2. 
Olha Pavelko, Inna Lazaryshyna, Liudmyla Dukhnovska, Svitlana Sharova, Tetiana Oliinyk, Iryna Donenko

Table 2. Construction enterprises net profit (loss) formation dynamics in 2014-2018 (UAH million)

\begin{tabular}{|c|c|c|c|c|c|c|c|c|c|c|}
\hline \multirow[b]{2}{*}{ № } & \multirow[b]{2}{*}{ Indexes } & \multirow[b]{2}{*}{2014} & \multirow[b]{2}{*}{2015} & \multirow[b]{2}{*}{2016} & \multirow[b]{2}{*}{2017} & \multirow[b]{2}{*}{2018} & \multicolumn{4}{|c|}{ Growth rate,\% } \\
\hline & & & & & & & $\begin{array}{c}2015 / \\
2014 \\
\end{array}$ & $\begin{array}{c}2016 / \\
2015 \\
\end{array}$ & $\begin{array}{c}2017 / \\
2016 \\
\end{array}$ & $\begin{array}{r}2018 / \\
2017 \\
\end{array}$ \\
\hline 1. & $\begin{array}{l}\text { Net income } \\
\text { from sales of } \\
\text { products }\end{array}$ & 149823,4 & 1716,8 & 169104,4 & 222483,3 & 301905,0 & 1,1 & 9850,0 & 131,6 & 135,7 \\
\hline 2. & $\begin{array}{c}\text { Other } \\
\text { operating } \\
\text { income }\end{array}$ & 9602,2 & 15021,3 & 13863,0 & 12453,7 & 14672,4 & 156,4 & 92,3 & 89,8 & 117,8 \\
\hline 3. & Other income & 19666,9 & 20458,7 & 16291,0 & 16419,0 & 21124,4 & 104,0 & 79,6 & 100,8 & 128,7 \\
\hline 4. & $\begin{array}{c}\text { Total net } \\
\text { income }\end{array}$ & 179092,6 & 177197,2 & 199258,7 & 251356,8 & 337704,5 & 98,9 & 112,5 & 126,1 & 134,4 \\
\hline 5. & $\begin{array}{c}\text { Operating } \\
\text { expenses }\end{array}$ & 150668,1 & 169240,2 & 183301,8 & 230712,1 & 306166,4 & 112,3 & 108,3 & 125,9 & 132,7 \\
\hline 6. & Other expenses & 55713,0 & 33030,8 & 25299,6 & 24180,4 & 25101,5 & 59,3 & 76,6 & 95,6 & 103,8 \\
\hline 7. & $\begin{array}{c}\text { Total expenses, } \\
\text { incl. }\end{array}$ & 207041,4 & 203059,1 & 209811,7 & 256371,1 & 333290,4 & 98,1 & 103,3 & 122,2 & 130,0 \\
\hline 8. & $\begin{array}{l}\text { Cost of sold } \\
\text { products } \\
\text { (goods, works, } \\
\text { services) }\end{array}$ & 113253,7 & 126832,3 & 148819,6 & 197652,3 & 268841,8 & 112,0 & 117,3 & 132,8 & 136,0 \\
\hline 9. & Profit (Net loss) & $-27948,8$ & $-25861,9$ & -10553 & $-5014,3$ & 4414,1 & 92,5 & 40,8 & 47,5 & - \\
\hline
\end{tabular}

Source: formed by the authors according to the State Statistics Service of Ukraine (application dated February 12, 2019).

Therefore, according to Table. 2, it can be concluded that the con-struction enterprises net income value in 2018 increased by $35,7 \%$, expens-es - respectively, increased by $30 \%$, which led to an improvement in the management financial result, namely: the net loss reduction from UAH 5014,3 million in 2017 to profit UAH 4414,1 million in 2018.

The construction development dynamics and construction enterpris-es' financial results are influenced by various factors, depicted in Fig. 5 .

The above information is generated based on financial statements. Qualitative characteristics of useful and meaningful financial statements include: understandability - financial statements that are unduly complicated can send up a red flag to banks and potential investors; transparency is key to success in today's business environment. Relevance - financial statements provide feedback on a company's performance and are used by banks and surety companies to predict a company's future success. Reliability - financial statements are management's responsibility and to be reliable. Comparability - financial statements that are comparable allow users to compare a company to another similar company or to compare a company's performance over some time [18].

The influence of the factors mentioned above on the construction enterprises' financial results, income, and expenses is shown in Table. 3.

The above factors mentioned affect all types of construction. They can be divided into stimulators that promote the construction development and the deterrents that suppress the claimed process. Almost all construction development outlined factors in the research affect the construction enterprises' financial performance and their main components - income and expenses.

Construction marketing association of USA stresses five factors for successful construction firms: Operations Visibility, Embrace Technology, Manage Complexity, Document Only What Matters, Avoid Litigation, which is not always acceptable for Ukrainian enterprise [19]. 
Fig. 5. Construction development factors (macroeconomic aspect)

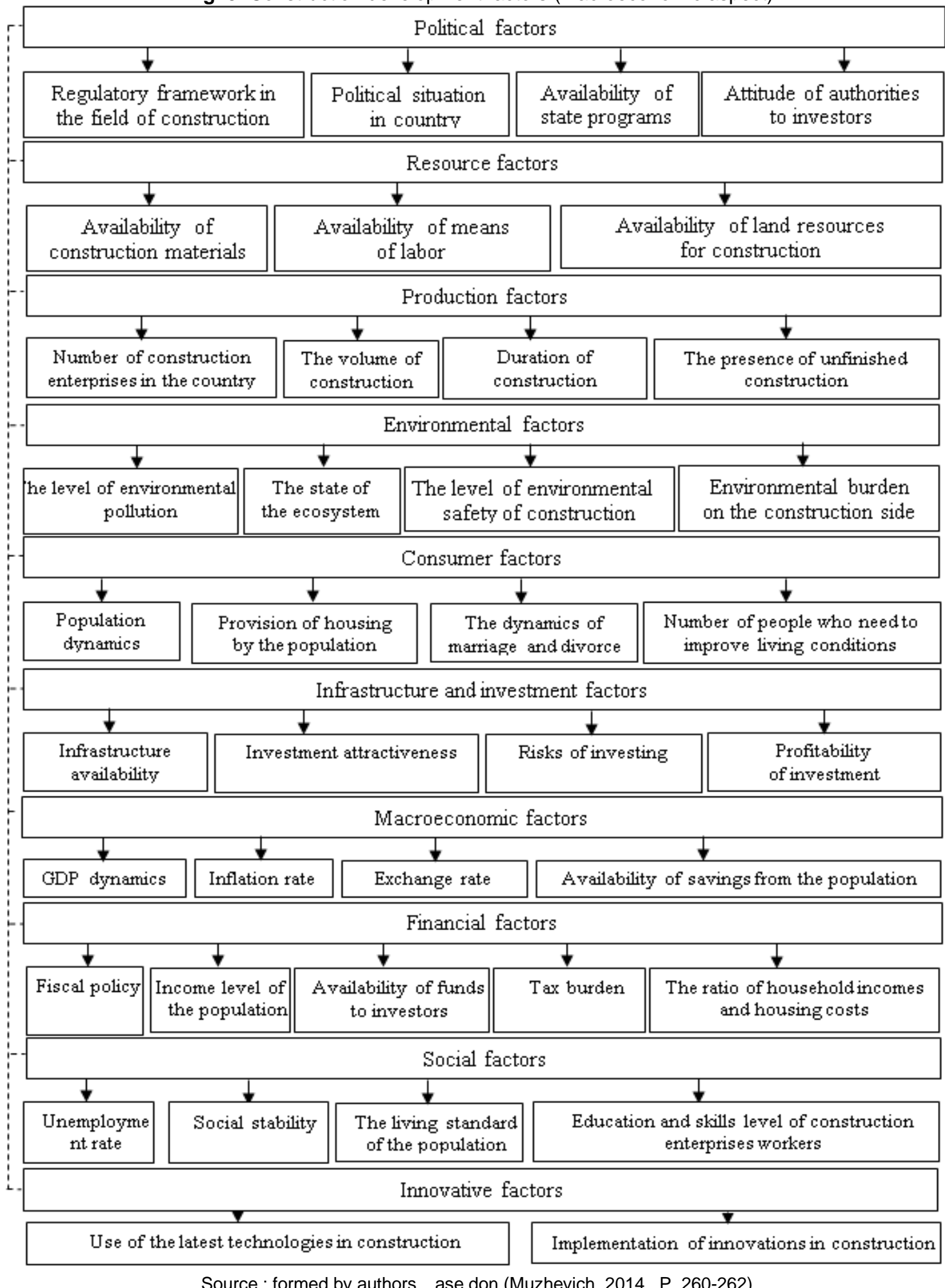

Source : formed by authors ase don (Muzhevich, 2014, P. 260-262). 
Olha Pavelko, Inna Lazaryshyna, Liudmyla Dukhnovska, Svitlana Sharova, Tetiana Oliinyk, Iryna Donenko

Table 3. Influence of construction development factors on construction companies' financial results, income, and expenses

\begin{tabular}{|c|c|c|c|c|}
\hline \multirow[b]{2}{*}{ № } & \multirow[b]{2}{*}{ Influence of construction development } & \multicolumn{3}{|c|}{ Influence on } \\
\hline & & income & expenses & $\begin{array}{l}\text { financial } \\
\text { results }\end{array}$ \\
\hline 1. & The regulatory framework in the field of construction & + & + & + \\
\hline 2. & The political situation in the country & + & + & + \\
\hline 3. & Availability of state programs & + & - & + \\
\hline 4. & The attitude of authorities to investors & - & - & - \\
\hline 5. & Availability of construction materials & - & + & + \\
\hline 6. & Availability of means of labor & - & + & + \\
\hline 7. & Availability of land resources for construction & + & + & + \\
\hline 8. & Number of construction enterprises in the country & + & - & + \\
\hline 9. & The volume of construction & - & + & + \\
\hline 10. & Duration of construction & + & + & + \\
\hline 11. & The presence of unfinished construction & + & + & + \\
\hline 12. & The level of environmental pollution & + & - & + \\
\hline 13. & The state of the ecosystem & + & - & + \\
\hline 14. & The level of environmental safety of construction & + & + & + \\
\hline 15. & The environmental burden on the construction side & + & + & + \\
\hline 16. & Population dynamics & + & - & + \\
\hline 17. & Provision of housing by the population & + & - & + \\
\hline 18. & The dynamics of marriage and divorce & + & - & + \\
\hline 19. & $\begin{array}{l}\text { Number of people who need to improve living } \\
\text { conditions }\end{array}$ & + & - & + \\
\hline 20. & Infrastructure availability & + & - & + \\
\hline 21. & Investment attractiveness & + & - & + \\
\hline 22. & Risks of investing & + & + & + \\
\hline 23. & Profitability of investment & + & - & + \\
\hline 24. & GDP dynamics & - & - & - \\
\hline 25. & Inflation rate & + & + & + \\
\hline 26. & Exchange rate & + & + & + \\
\hline 27. & Availability of savings from the population & + & - & + \\
\hline 28. & Fiscal policy & + & + & + \\
\hline 29. & Income level of the population & + & - & + \\
\hline 30. & Availability of funds to investors & + & - & + \\
\hline 31. & Tax burden & + & + & + \\
\hline 32. & The ratio of household incomes and housing costs & + & - & + \\
\hline 33. & Unemployment rate & + & - & + \\
\hline 34. & Social stability & + & - & + \\
\hline 35. & The living standard of the population & + & - & + \\
\hline 36. & $\begin{array}{l}\text { Education and skills level of construction enterprises } \\
\text { workers }\end{array}$ & - & + & + \\
\hline 37. & Use of the latest technologies in construction & + & + & + \\
\hline 38. & Implementation of innovations in construction & + & + & + \\
\hline
\end{tabular}
Source: formed by the authors.

\section{Conclusions.}

The conducted research gives reasons to state the significant role of the country macroeconomic environment in the construction enterprises functioning and the purport of their financial results. It 
was established that construction has become more active in recent years. The highest residential and non-residential construction rates and the engineering structures construction in 2016 were observed in Kyiv. Each year, the largest capital investments are characterized by engineering structures, in contrast to residential and non-residential buildings.

From the macroeconomics standpoint, the construction development factors are proposed to be distinguished in the following groups: political, raw, industrial, environmental, consumer, infrastructure and investment, macroeconomic, financial, social, and innovation. Their influence on financial construction enterprises activity results and the generating factors - incomes and expenses, was clarified. Further research will highlight the governance levels in the construction sector, namely: from the standpoint of macro- and microeconomics.

\section{References}

1. Abdul, R., Matthew, H. R., Zafar, U., \& Ghaffar, I. (2010). Analyzing the dynamics of the global construction industry: past, present and future. Benchmarking, 17(2), pp. 232-252. https://doi.org/10.1108/14635771011036320

2. Muzhevich, N.V. (2014). Accounting and analysis of maintenance and operation costs construction equipment: dis. for science. Art. Ph.D., special. 08.00.09 - accounting, analysis and audit (by type of economic activity). - Ternopil: TNEU, 243 p. (in Ukrainian)

3. Verhogljadova, N.I., Goncharenko, M.F., Levchyns'kyj, D.L. \& Shheglova, O. Ju. (2011). Prospects for the development of the investment process in the housing market: monograph, Dnepropetrovsk: Svidler Publishing House, 566 p. (in Ukrainian)

4. Tkachenko, V., Kwilinski, A., Klymchuk, M., \& Tkachenko, I. (2019). The Economic-Mathematical Development of Buildings Construction Model Optimization on the basis of Digital Economy. Management Systems in Production Engineering, 27(2), 119-123. http://doi.org/10.1515/mspe2019-0020

5. Miśkiewicz, R, \& Wolniak, R. (2020). Practical Application of the Industry 4.0 Concept in a Steel Company. Sustainability, 12(14), 5776. https://doi.org/10.3390/su12145776

6. Zakharkin, O., Basantsov, I., Shcherbachenko, V., Zakharkina, L. (2019). Public-private partnership as an effective tool in R\&D activity. Proceedings of the 33rd International Business Information Management Association Conference, IBIMA 2019: Education Excellence and Innovation Management through Vision 2020. pp. 6674-6678.

7. Pimonenko, T., Prokopenko, O., \& Dado, J. (2017). Net zero house: EU experience in Ukrainian conditions. International Journal of Ecological Economics and Statistics, 38(4), pp. 46-57.

8. Getsov, P., Bo, W., Mardirossian, G. Nedkov, R., Stoyanov, S., Prokopenko, O., Boyanov, P. (2017). Equipment for evaluation of the characteristics of electronic-optic converters. Comptes Rendus de L'Academie Bulgare des Sciences, 70(11), pp. 1575-1578.

9. Kwilinski, A., Dzwigol, H., \& Dementyev, V. (2020). Model of Entrepreneurship Financial Activity of the Transnational Company Based on Intellectual Technology. International Journal of Entrepreneurship, 24 (Special Issue: Entrepreneurship, Innovation Management, and Sustainability), 1-5. Retrieved from https://www.abacademies.org/articles/Model-ofEntrepreneurship-Financial-Activity-of-the-Transnational-Company-Based-on-IntellectualTechnology.pdf

10. Mura, L., Buleca, J., Hajduova, Z., \& Andrejkovic, M. (2015). Quantitative financial analysis of small and medium food enterprises in a developing country. Transformations in Business and Economics, 14(1), pp. 212-224.

11. Shpak, N., Seliuchenko, N., Kharchuk, V., Kosar, N., Sroka, W. (2019). Evaluation of Product Competitiveness: A Case Study Analysis. Organizacija, vol. 52(2), pages 107-125. http://doi.org/10.2478/orga-2019-0008. 
12. Prokopenko, O., Slatvinskyi, M., Bikoshkurska, N., Biloshkurskyi, M., \& Omelyanenko, V. (2019). Methodology of national investment and innovation security analytics. Problems and Perspectives in Management, 17(1), pp. 380-394, 2019. http://dx.doi.org/10.21511/ppm.17(1).2019.33

13. Binda, J., Prokopenko, M., Ramskyi, A., Shuplat, O., Halan, L., \& Mykhaylenko, D. (2020). Assessment of investment attractiveness of industrial enterprises. International Journal of Management, 11(2), pp. 27-35. Retrieved from http://iaeme.com/MasterAdmin/Journal_uploads/JMM/VOLUME_11_ISSUE_2/IJM_11_02_004.pdf

14. Yashin, S., \& Korobova, J. (2018). Estimation of the sustainability of the innovative development of the regional industrial sector. Innovations, 12. Retrieved from https://maginnov.ru/en/magazine/archive/2018/innovations-n12-2018/estimation-of-thesustainability-of-the-innovative-development-of-the-regional-industrial-sector

15. The State Statistics Service of Ukraine. Retrieved from http://www.ukrstat.gov.ua/

16. Lang, J. (2016). LaSalle Global Real Estate Transparency Index. Retrieved from http://www.jll.com/GRETI.

17. Construction of UK: An economic analysis of the sector (2013). Retrieved from https://assets.publishing.service.gov.uk/government/uploads/system/uploads/attachment_data/ file/210060/bis-13-958-uk-construction-an-economic-analysis-of-sector.pdf.

18. Financial Statements Guide for Construction Companies (2015). Retrieved from http://www.ledgersonline.com/blog/financial-statements-guide-for-construction-companies.

19. Five Success Factors for Construction Firms (2016). Retrieved from http://blog.constructionmarketingassociation.org/5-success-factors-for-construction-fi 